\section{Category}

Metal-Mediated

Synthesis

\section{Key words}

tin

boron

copper

alkynoates

tributyltin methoxide

trisubstituted alkenylstannanes

T. WAKAMATSU, K. NAGAO, H. OHMIYA,* M. SAWAMURA* (HOKKAIDO UNIVERSITY, SAPPORO, JAPAN)

Synthesis of Trisubstituted Alkenylstannanes through Copper-Catalyzed Three-Component Coupling of Alkylboranes, Alkynoates and Tributyltin Methoxide Angew. Chem. Int. Ed. 2013, 52, 11620-11623.

\title{
Synthesis of Trisubstituted Alkenylstannanes Starting from Alkynoates
}

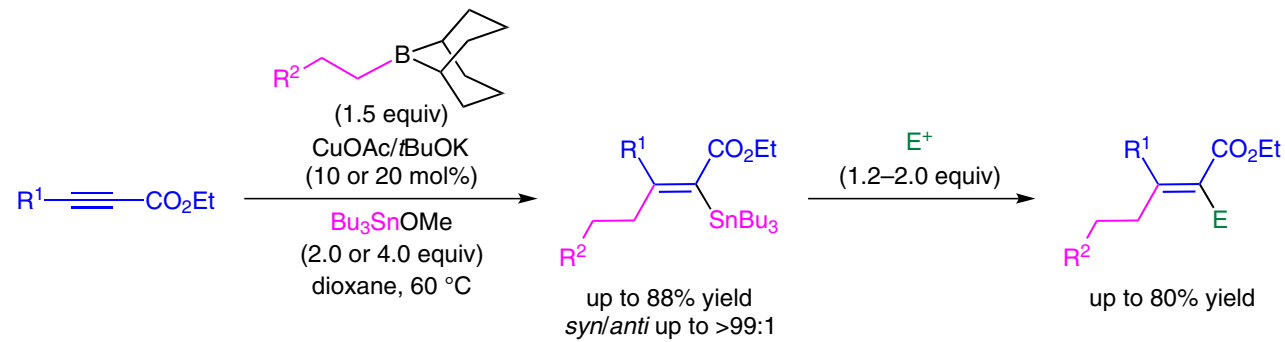

$\mathrm{R}^{1}=\mathrm{Ph}, n$-Bu, $n$-Pent, $\left(\mathrm{CH}_{2}\right)_{3}$ phthalimide, $\left(\mathrm{CH}_{2}\right)_{4} \mathrm{OTHP}, \mathrm{C}(\mathrm{Me})_{2} \mathrm{CH}_{2} \mathrm{CO}_{2} \mathrm{Me}, 4-\mathrm{BrC}_{6} \mathrm{H}_{4},\left(\mathrm{CH}_{2}\right)_{3} \mathrm{OTIPS}$ $\mathrm{R}^{2}=\mathrm{Ph}, 4-\mathrm{MeOC}_{6} \mathrm{H}_{4}, 4-\mathrm{MeO}_{2} \mathrm{CC}_{6} \mathrm{H}_{4}, 2-\mathrm{MeC}_{6} \mathrm{H}_{4}, \mathrm{Me}, \mathrm{CH}_{2} \mathrm{OTHP}, \mathrm{CH}_{2} \mathrm{OBn}, 4-\mathrm{FC}_{6} \mathrm{H}_{4}$, 2-thienyl derivative

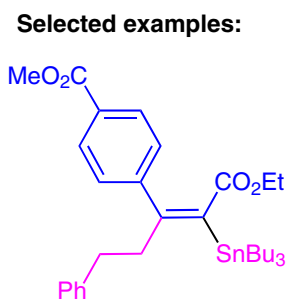

$61 \%$ yield syn/anti $=91: 9$

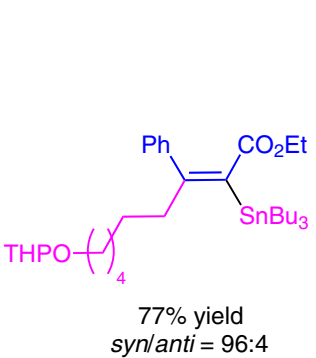

syn/anti $=96: 4$

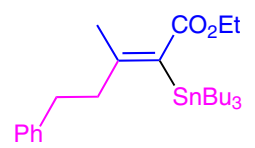

$49 \%$ yield syn/anti > 99:1

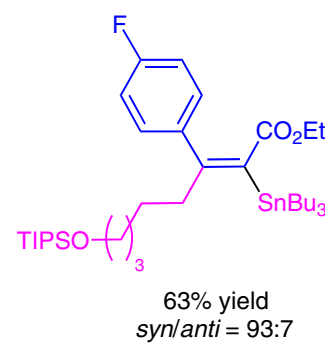

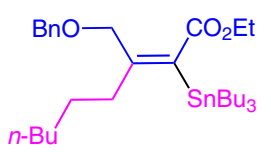

$74 \%$ yield syn/anti > 99:1

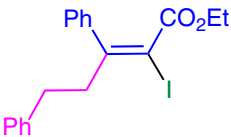

$80 \%$ yield
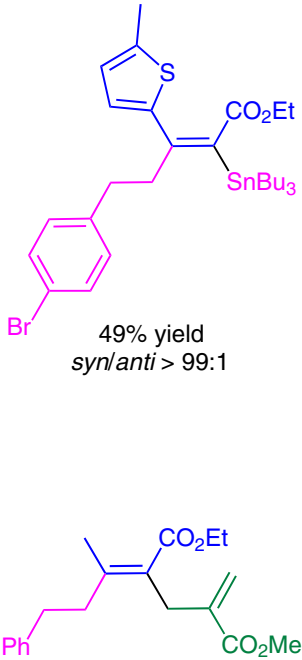

$77 \%$ yield
Significance: The authors report a highly regioselective copper-catalyzed synthesis of trisubstituted alkenylstannanes. Through a three-component coupling of alkylboranes, alkynoates and tributyltin methoxide, these trisubstituted alkenylstannanes are obtained in good yields and with high syn selectivity. The appropriate alkylboranes are easily accessible by hydroboration of the corresponding alkenes with the 9-borabicyclo[3.3.1]nonane (9-BBN-H) dimer.
Comment: Standard methods for the synthesis of alkenylstannanes described by Shirakawa and Hiyama include the palladium- or nickel-catalyzed carbostannylation of internal alkynes with organostannanes which are somewhat difficult to prepare. 